\title{
In vitro antimicrobial sensitivity of Neisseria gonorrhoeae from Rwanda
}

\author{
J BOGAERTS,* J VANDEPITTE, $\dagger$ E VAN DYCK, $\ddagger$ R VANHOOF, $\S$ M DEKEGEL, $\S$ AND \\ P PIOT $\ddagger$
}

From the *Centre Hospitalier de Kigali, Rwanda, the $\dagger$ Department of Microbiology, St Raphael University Hospital, Leuven, the $\ddagger$ Institute of Tropical Medicine, Antwerp, and the §Pasteur Institute of Brabant, Brussels, Belgium

SUMMARY The in vitro sensitivity of 104 isolates of Neisseria gonorrhoeae to six antimicrobial agents was tested. More than $50 \%$ of the isolates produced penicillinase. Of those that did not produce penicillinase, $26 \%$ were resistant (minimum inhibitory concentration (MIC)) $\geq 0.5 \mathrm{mg} / \mathrm{l}$ ), and $68 \%$ showed a decreased sentitivity for penicillin G $(0.06 \leq \mathrm{MIC} \leq 0.25 \mathrm{mg} / \mathrm{l})$. Twenty six per cent and $50 \%$ of the strains, respectively, showed a decreased sensitivity to thiamphenicol (MIC $\geq 1 \mathrm{mg} / \mathrm{l}$ ) and tetracycline (MIC $\geq 2 \mathrm{mg} / \mathrm{l}$ ). All isolates were sensitive to spectinomycin, kanamycin, and norfloxacin. Of 20 penicillinase producing $N$ gonorrhoeae (PPNG) isolates examined, seven contained the 3.4 megadalton R-plasmid, another seven contained both the 3.4 megadalton and 22.5 megadalton plasmids, five the 4.3 megadalton and 22.5 megadalton plasmids, and one isolate harboured both the 3.4 and 4.3 R-plasmids, together with the 22.5 megadalton plasmid. A disturbing increase in resistance to penicillin has been observed since the publication of earlier surveys, and the clinical implications of these findings are discussed.

\section{Introduction}

Uncomplicated gonorrhoea is extremely common in Rwanda. The official figures, varying between 6000 and 15000 cases a year for a population of about five million people, represent only a fraction of the total number of cases. ${ }^{1}$ Penicillinase producing strains of Neisseria gonorrhoeae (PPNG) have never been isolated in the past, and until the last survey of 1978 most strains had been found to be sensitive to penicillin $\mathrm{G.}^{23}$

Towards the end of 1982 an increase in the number of patients unsuccessfully treated with penicillin prompted us to search for the presence of PPNG strains and to re-evaluate the antimicrobial sensitivity of $N$ gonorrhoeae strains from Rwanda.

Adress for reprints: Professor J Vandepitte, Department of Microbiology, St Raphael University Hospital, B-3000 Leuven, Belgium

Accepted for publication 26 November 1985

\section{Materials and methods}

From May to December 1984, 305 consecutive isolates of $N$ gonorrhoeae were cultured at the laboratory of the Centre Hospitalier de Kigali, Rwanda, stored at $-20^{\circ} \mathrm{C}$ until needed, and sent to the Institute of Tropical Medicine, Antwerp, Belgium. Only $104(34 \cdot 1 \%)$ survived transit, of which 54 (51.9\%) were PPNG strains.

The identity of all isolates was confirmed by Gram stain, oxidase reaction, and degradation of dextrose, but not sucrose, lactose, or maltose. The presence of penicillinase was determined by the chromogenic cephalosporin test. ${ }^{4}$ Minimum inhibitory concentrations (MICs) were determined by an agar dilution technique úsing $10^{5}$ colony forming units (cfu) on diagnostic sensitivity agar (Oxoid) supplemented with $1 \%$ IsoVitalex and $2 \%$ haemoglobin. Cultures were incubated for 24 hours at $37^{\circ} \mathrm{C}$ in a $5 \%$ carbon dioxide atmosphere. The MIC was defined as the lowest concentration of antimicrobial agent that inhibited visible growth. The antimicrobial agents were pro- 
vided by: the Laboratory of Standards, Ministry of Health, Brussels (penicillin, tetracycline hydrochloride, and thiamphenicol), Upjohn, Puurs, Belgium(spectinomycin); Bristol, Brussels (kanamycin); and Merck, Sharp and Dohme, Brussels (norfloxacin). Plasmids were extracted according to the method of Birnboim and Doly ${ }^{5}$ and prepared for transmission electron microscopy by the method of Kleinschmidt and Zahn. ${ }^{6}$

The $X^{2}$ test was used to compare differences in sentitivity between PPNG and non-PPNG strains and to compare the sensitivity pattern for different antimicrobials.

\section{Results}

Table I shows the sensitivity to six antibiotics for both PPNG and non-PPNG strains. In $68 \%$ of non-PPNG strains a decreased sensitivity to penicillin was observed $(0.06 \mathrm{mg} / 1 \leq \mathrm{MIC} \leq 0.25 \mathrm{mg} / 1$ of penicillin $)$, and $26 \%$ showed a MIC of $\geq 0.5 \mathrm{mg} / 1$ : the latter value corresponds to the high failure rate achieved when the standard penicillin regimen of $2.88 \mathrm{~g}$ procaine penicillin plus $1 \mathrm{~g}$ of probenicid is used. ${ }^{7}$ All PPNG strains showed a MIC of $\geq 16 \mathrm{mg} / 1$ of penicillin. Resistance to tetracycline was common: $53.7 \%$ of PPNG and $46 \%$ of non-PPNG strains yielded MICs of $\geq 2 \mathrm{mg} / 1$. A failure rate of $13 \%$ may be expected for strains with such resistance levels. ${ }^{8}$ PPNG strains were significantly less resistant to thiamphenicol than non-PPNG strains: $16.6 \%$ and $36 \%$, respectively, showed decreased sensitivity (MIC $\geq 1 \mathrm{mg} / 1$ of thiamphenicol; $x^{2}=4.09 ; p<0.05$ ).

A strong correlation existed between resistance to penicillin and tetracycline $\left(x^{2}=8.22 ; p<0.01\right)$ and (PPNG strains excepted) between resistance to penicillin and thiamphenicol $\left(\chi^{2}=6.58 ; \mathrm{p}<0.05\right)$. Resistance to thiamphenicol was also strongly correlated with resistance to tetracycline, irrespective of the presence of penicillinase $\left(x^{2}\right.$ with PPNG $=6 \cdot 22$; $p<0.05 . x^{2}$ without PPNG $\left.=12.8 ; p<0.01\right)$.

All isolates were fully sensitive to kanamycin, spectinomycin, and norfloxacin, and no appreciable differences could be observed between PPNG and non-PPNG strains.

TABLE I In vitro sensitivities (minimum inhibitory concentrations (MICs)) of 104 clinical isolates of Neisseria gonorrhoeae from Rwanda

\begin{tabular}{|c|c|c|c|c|c|c|c|c|c|c|c|c|c|c|}
\hline \multirow{2}{*}{$\begin{array}{l}\text { Antimicrobial } \\
\text { agent }\end{array}$} & \multicolumn{8}{|c|}{ No of PPNG/non-PPNG strains showing MICs $(\mathrm{mg} / \mathrm{l})$ of: } & \multirow[b]{2}{*}{1} & \multirow[b]{2}{*}{2} & \multirow[b]{2}{*}{4} & \multirow[b]{2}{*}{8} & \multirow[b]{2}{*}{$16+$} & \multirow[b]{2}{*}{32} \\
\hline & 0004 & 0.008 & 0015 & 0.030 & 0.06 & $012^{*}$ & $0 \cdot 25$ & 0.5 & & & & & & \\
\hline Penicillin G & & & & $0 / 3$ & $0 / 10$ & $0 / 22$ & $0 / 2$ & $0 / 9$ & $0 / 1$ & $0 / 3$ & & & $54 / 0$ & \\
\hline Tetracycline & & & & & & & & $2 / 9$ & $23 / 18$ & $19 / 14$ & $2 / 6$ & $8 / 3$ & & \\
\hline Spectinomycin & & & & & & & & & & & $1 / 1$ & $5 / 12$ & $47 / 36$ & $1 / 1$ \\
\hline Thiamphenicol & & & & & & $9 / 9$ & $31 / 12$ & $5 / 11$ & $9 / 17$ & $0 / 1$ & & & & \\
\hline Kanamycin & & & & & & & & & & & $2 / 3$ & $16 / 28$ & $36 / 19$ & \\
\hline Norfloxacin & $0 / 3$ & $0 / 2$ & $23 / 19$ & $18 / 18$ & $13 / 7$ & $0 / 1$ & & & & & & & & \\
\hline
\end{tabular}

PPNG = penicillinase producing $\mathbf{N}$ gonorrhoea.

* MIC thiamphenicol $\leq 0.125 \mathrm{mg} / 1$;

+ MIC penicillin $\geq 16 \mathrm{mg} / 1$ (= PPNG).

TABLE II Evolution of in vitro sensitivity (minimum inhibitory concentrations (MICs)) to penicillin of Rwandese Neisseria gonorrhoeae

\begin{tabular}{|c|c|c|c|c|c|c|}
\hline \multirow[b]{2}{*}{$\begin{array}{l}\text { Year of } \\
\text { isolation }\end{array}$} & \multirow[b]{2}{*}{ Reference } & \multirow[b]{2}{*}{$\begin{array}{l}\text { No of } \\
\text { strains }\end{array}$} & \multicolumn{3}{|c|}{ No (\%) of strains showing MIC (mg/l) of: } & \multirow[b]{2}{*}{$\begin{array}{l}\text { No (\%) of } \\
\text { PPNG strains }\end{array}$} \\
\hline & & & 0.03 & $0 \cdot 06-0 \cdot 25$ & 0.05 & \\
\hline 1976 & 2 & 53 & $23(43 \cdot 4)$ & $30(56 \cdot 6)$ & & \\
\hline 1978 & 3 & 41 & $6(14 \cdot 6)$ & $18(43 \cdot 9)$ & $17(41 \cdot 5)$ & \\
\hline 1983 & Unpublished obseryations & 231 & \multicolumn{2}{|c|}{ MICs not measured } & & $42(18 \cdot 2)$ \\
\hline 1984 & Present paper & 104 & $3(6 \cdot 0)^{*}$ & $34(68 \cdot 0)^{*}$ & $13(26 \cdot 0)^{*}$ & $54(51.9)$ \\
\hline
\end{tabular}

PPNG = penicillinase producing strains of $N$ gonorrhoeae.

* MICs for only 50 non-PPNG strains. 
Table II shows the evolution of the in vitro sensitivity to penicillin of the Rwandese isolates from 1976 onwards. No information is available for the period 1979-82, but the presence of PPNG strains was only clinically suspected at the end of 1982 . In 198342 of $231(18 \cdot 2 \%)$ isolates were penicillinase positive and in 1984204 of $504(40.5 \%)$ tested strains were penicillinase positive.

Table III summarises the results of the plasmid analysis of 20 PPNG isolates. Seven contained the 3.4 megadalton R-plasmid, another seven both the 3.4 megadalton and 22.5 megadalton plasmids, five the 4.3 megadalton and 22.5 megadalton plasmids, and one isolate harboured both the 3.4 and $4.3 \mathrm{R}$-plasmids, together with the 22.5 megadalton plasmid.

TABLE III Plasmids in 20 penicillinase producing strains of Neisseria gonorrhoeae isolated in Rwanda in 1984

\begin{tabular}{ll}
\hline Plasmid size (megadaltons) & No (\%) \\
\hline $3 \cdot 4$ & $7(35)$ \\
$3 \cdot 4+22 \cdot 5$ & $7(35)$ \\
$4 \cdot 3+22 \cdot 5$ & $5(25)$ \\
$3 \cdot 4+4 \cdot 3+22 \cdot 5$ & $1(5)$ \\
\hline
\end{tabular}

\section{Discussion}

From our results it is obvious that penicillin $G$ no longer has any place in the first line treatment of gonorrhoea in Rwanda. A group of experts from the World Health Organisation has recently proposed alternative regimens for areas with a high prevalence of PPNG strains or a high prevalence of chromosomally resistant strains. ${ }^{8}$ These regimens include second and third generation cephalosporins and spectinomycin, which are all highly effective in the treatment of gonorrhoea - but also very expensive. Table IV shows the cost of the different alternative regimens currently available in Rwanda.

TABLE IV Cost of alternative treatment regimens in Rwanda (as at April 1985)

\begin{tabular}{|c|c|c|c|}
\hline & Dose (g) & $\begin{array}{l}\text { Kwandese } \\
\text { francs }\end{array}$ & $\begin{array}{l}\text { Equivalent } \\
\text { in American } \\
\text { dollars }\end{array}$ \\
\hline $\begin{array}{l}\text { Cefotaxime } \\
\text { Spectinomycin } \\
\text { Kanamycin } \\
\text { Thiamphenicol } \\
\text { Procaine penicillin } \\
\text { with } 1 \mathrm{~g} \text { probenicid }\end{array}$ & $\begin{array}{l}1 \\
2 \\
2 \\
2 \cdot 5 \\
2 \cdot 88\end{array}$ & $\begin{array}{l}910 \\
750 \\
550 \\
300 \\
230\end{array}$ & $\begin{array}{r}10 \cdot 00 \\
8 \cdot 24 \\
6 \cdot 04 \\
3.29 \\
2.52\end{array}$ \\
\hline
\end{tabular}

Rate of exchange: 90.5 Rwanda francs $=$ US\$1 $=£ 0.8$.
Second and third generation cephalosporins should not be used in developing areas with high sexual promiscuity, irrespective of the cost of the treatment, in view of the risk of the emergence of increasingly resistant strains. Their use should be restricted, therefore, to the inpatient treatment of serious infections with multiresistant Gram negative micro-organisms, which are extremely common in the tropics.

Though we cannot rule out the presence of strains resistant to spectinomycin in Rwanda, we believe that their prevalance is very low and that this drug is the best alternative for treating uncomplicated gonorrhoea. A list of less expensive, but also less effective, drugs was developed by the WHO experts. It includes: kanamycin $(2 \mathrm{~g})$ by intramuscular injection, thiamphenicol $(2.5 \mathrm{~g})$ in a single oral dose, and cotrimoxazole (trimethoprim $(80 \mathrm{mg}$ ) sulphamethoxazole (400 mg) 10 tablets taken once daily for three days. As multiple dose treatments are not indicated for developing countries (due to the considerable risk that the drug may be put aside for later use or sold to other patients), co-trimoxazole has no place in the treatment of gonorrhoea.

Our in vitro results indicate that kanamycin is a suitable alternative for spectinomycin. It is effective in the treatment of both PPNG and non-PPNG strains, ${ }^{910}$ but this drug is too expensive for the first line treatment of gonorrhoea. Furthermore, no information exists on the toxicity of this dose. A failure rate of $1.2 .5 \%$ was observed in Thailand, ${ }^{11}$ but $30 \%$ of the local strains had a MIC of $\geq 32 \mathrm{mg} / 1$ kanamycin. ${ }^{12}$ In Singapore $22 \%$ of the isolates showed a MIC of $32 \mathrm{mg} / 1$ kanamycin ${ }^{13}$ with a therapeutic failure rate of $11 \% .{ }^{14}$

Thiamphenicol is cheap, can be given as a single oral dose, and shows no important side effects, though its potential for irreversible haematotoxic damage is still debatable. Treatment failures have been correlated with MICs of $\geq 1 \mathrm{mg} / 1 .^{15}{ }^{16}$ Thus infections with strains havng a MIC of $2 \mathrm{mg} / \mathrm{l}$ failed to respond in $4.5 \%{ }^{15}$ and $14.3 \%{ }^{16}$ of patients when treated with a $2.5 \mathrm{~g}$ single oral dose. The newer quinolones seem to be the most promising agents in the treatment of gonorrhoea. Their in vitro activity is extremely high 1719 and the peak serum concentrations largely exceed the observed MICs. ${ }^{20}$ More information, however, is needed on their clinical efficacy, absence of serious side effects, and cost of the treatment.

Our results confirm that both types of R-plasmids the "Asian" and the "African" types - are now occurring among PPNG strains in Africa, as previously reported from Kenya. ${ }^{21}$ Moreover, half of the isolates harbouring the 3.4 megadalton plasmid are also carrying the longer transfer factor, in contrast to the earlier PPNG isolates originally described from Africa. ${ }^{22} 23$ This acquisition of the transfer plasmid may explain the dramatic increase in the proportion of PPNG strains in Africa in recent years. To the best of our 
knowledge the concomitant occurrence of both the 3.4 and 4.3 megadalton plasmids in the same isolate has not been reported before, and it further illustrates the potential for exchange of plasmids among $N$ gonorrhoeae strains.

We can speculate that PPNG strains were imported from neighbouring Kenya, a country that has extensive commercial relations with Rwanda, and where the first PPNG strains were isolated in June $1981 . .^{21}$ Continuous monitoring of microbial sensitivity is imperative for optimal therapeutic regimens to be selected.

\section{References}

1. Meheus A, Habimana A. Maladies transmises par voie sexuelle (MST). In: Santée et maladies au Rwanda. Bruxelles: Administration Générale de la Coopération au Développement, 1982:481-96.

2. Piot P, Meheus AZ, Van Dyck E, Bosmans E, Nakure S. La sensibilité aux antibiotiques de Neisseria gonorrhoeae au Rwanda. Ann Soc Belg Méd Trop 1978;58:33-8.

3. Piot P, Van Dyck E, Colaert J, Ursi JP, Bosmans E, Meheus A. Antibiotic susceptibility of Neisseria gonorrhoeae strains from Europe and Africa. Antimicrob Agents Chemother 1979;15:535-9.

4. O'Callaghan CM, Morris A, Kirby SM, Shingler AM. Novel method for detection of beta-lactamase by using a chromogenic cephalosporin substrate. Antimicrob Agents Chemother 1972;1:282-8.

5. Birnboim HC, Doly J. A rapid alkaline extraction procedure for screening recombinant plasmid DNA. Nucleic Acids Res 1979;7:1513-23.

6. Kleinschmidt AK, Zahn RK. Ueber Desoxyribonucleinesäure Moleküln in Protein-Mischfilmen. $Z$ Naturforsch [C] 1959;146:770-9.

7. Guinan ME, Biddle J, Thornsberry C, Reynolds G, Zaidi A, Wiesner $P$. The national gonorrhoea therapy monitoring study. I. Review of treatment results and of in vitro antibiotic susceptibility, 1972-1978. Sex Transm Dis 1979;6 (suppl 2):93102.

8. World Health Organisation. Current treatments in the control of sexually transmitted diseases. WHO/VDT/83. Geneva:WHO, 1983;433:7-11.

9. Fischnaller JE, Pedersen AHB, Ronald AR, Bonin P, Tronca EL. Kanamycin sulfate in the treatment of acute gonorrheal urethritis in man. JAMA 1968;203:909-12.

10. Sng EH, Rajan VS, Khoo R, Tan T, Koe SL. Antibiotic susceptibility of $\beta$ lactamase producing and non-producing Neisseria gonorrhoeae. Asian J Infect Dis. 1977;1:17-9.

11 Panikabutra K, Ariyarit C, Chitwarakorn A, Warnnisson T, Saensanoh C. Sensitivity to penicillin, thiamphenicol, kanamycin, cefoxitin and spectinomycin of penicillinaseproducing Neisseria gonorrhoeae in Bangkok. Relation to the results of treatment. J Med Assoc Thai 1982;65:316-24.

12. Brown S, Warnnisson T, Biddle J, Panikabutra K, Traisupa A. Antimicrobial resistance of Neisseria gonorrhoeae in Bangkok: is single-dose treatment passé. Lancet 1982;ii:1366-8.

13. Sng EH, Lim AL, Yeo KL. Susceptibility to antimicrobials of Neisseria gonorrhoeae isolated in Singapore: implication on the need for more effective treatment regimens and control strategies. British Joumal of Venereal Diseases 1984;60:374-9.

14. Rajan VS. The treatment of gonorrhea - beta lactamase producers. Ann Acad Med Singapore 1983;12:103-8.

15. Tupasi TE, Crisologo LB, Torres CA, Calubiran OV. Comparison of spectinomycin, cefuroxime, thiamphenicol and penicillin $G$ in the treatment of uncomplicated gonococcal infections in woman. $J$ Infect Dis 1982;145:583.

16. Nsanze H, D'Costa LJ, Owili DM, Ilako F, Achola N, Piot P. Treatment of gonorrhea with single-dose thiamphenicol in Kenya. Sex Transm Dis 1984;11 (supp 1):376-8.

17. Peeters $M$, Van Dyck E, Piot $P$. In vitro activities of the spectinomycin analog U-63366 and four quinolone derivatives against Neisseria gonorrhoeae. Antimicrob Agents Chemother 1984;26:608-9.

18. Kahn MY, Siddiqui Y, Grunninger RP. Comparative in vitro activity of MK-0366 and other selected oral antimicrobial agents against Neisseria gonorrhoeae. Antimicrob Agents Chemother 1981;20:265-6.

19. Crider SR, Colby SD, Miller LK, Harrison WO, Kerbs SBJ, Berg SW. Treatment of penicillin-resistant Neisseria gonorrhoeae with oral norfloxacin. N Engl J Med 1984;311:137-40.

20. Boppana VK, Swanson BN. Determination of norfloxacin, a new nalidixic analog, in human serum and urine by highperformance liquid chromatography. Antimicrob Agents Chemother 1982;21:808-10.

21. Plummer FA, D'Costa LJ, Nsanze H, et al. Development of endemic penicillinase-producing Neisseria gonorrheae in Kenya. In: Schoolnik GK, ed. The pathogenic neisseriae Washington: American Society of Microbiology, 1985:101-7.

22. Perine PL, Thornsberry $C$, Schalla $W$ et al. Evidence for two distinct types of penicillinase-producing Neisseria gonorrhoeae. Lancet 1977; ii:993-5.

23. Roberts M, Piot P, Falkow S. The ecology of gonococcal plasmids. J Gen Microbiol 1979;114:491-3. 